the university today ?" even sounds suspiciously like a prescription.

$\mathrm{Mr}$ Thorne is describing his own counselling philosophy and if some students find his approach helpful, then that is fine. We suspect, however, that many would find the kind of transaction he described threatening (for instance, young people who have experienced parents as "smothering"). It would be a pity if his readers were to think that all student counselling is as he describes it. There is even an uncomfortable feeling that $\mathrm{Mr}$ Thorne believes that his is the only way-for example, his comment about "Dr Bloggins who professes to have been counselling students for years" and suddenly begins to see the light. Mr Thorne's light?

Michael JaCOBS JAMES L CRIGHTON

Student Health Service, University of Leicester

SIR,-I read Mr Brian Thorne's article on this subject (20 November, $p$ 1245) with some sadness, caused by what I felt throughout the article to be his variations on the theme of an as yet inadequately bridged gulf between professional counsellor and the psychiatrist.

I was therefore encouraged to read that $\mathrm{Mr}$ Thorne referred to David Lewis, counsellor at University College, Swansea, as his colleague. David Lewis and I worked closely together in the Cambridge Psychiatric Service from 1961 to 1964 . When he left us to return to his native Wales and to higher things $I$, and many of us here, regretted the loss of a skilled and warm-hearted colleague with whom it was a pleasure to work in close co-operation. That this is not always so emerges from $\mathrm{Mr}$ Thorne's article. I hope, however, that co-operation between psychiatrists and counsellors, whatever the counsellor's initia professional training, is increasingly the rule rather than the exception. I agree with $\mathrm{Mr}$ Thorne's final section on counsellors and doctors. The last thing we want to see in Britain is the kind of alienation between the medical profession and non-medically qualified counsellors and psychotherapists which is present in some parts of the world.

Finally, may I correct one misleading statement in $\mathrm{Mr}$ Thorne's article when he implies that doctors, and principally doctors, report that about $15 \%$ or more of students suffer from psychiatric symptoms? In fact, the first reference to any such percentage of which I am aware was made in 1933 by J R Angel, who was then President of Yale University, who wrote: " $10-15 \%$ of our college students suffer from some emotional or personality difficulties sufficiently serious to diminish very much their effectiveness and happiness." Subsequently many of us have confirmed that this proportion is about the same in many universities in many parts of the world. One of the first to do so was Dr Ronald Still, who, when medical officer to the University of Leeds, reported in the 1950s that the incidence of psychological symptoms of all degrees of severity in the thousands of students who had been seen in the Leeds University Health Service since 1949 was about $16 \%$, of whom just under $1 \%$ had severe symptoms, about $4 \frac{1}{2} \%$ moderately severe symptoms, and a further $10 \frac{1}{2} \%$ had mild symptoms. In confirming these figures it has been repeatedly emphasised that the $1 \%$ of students with severe symptoms commonly need inpatient psychiatric treatment, that the $5^{\circ}$ of students with moderately severe symptoms require specialist psychiatric, psychotherapeutic, or professional counselling treatment, and the remaining $10^{\%}$ or so will have problems beyond their own unaided efforts to solve and so will require help from someone with knowledge and experience of matters of this kind, though not necessarily, or even commonly, from a doctor. Further confirmation of the extent of actual illness in students came from the late Dr Kidd, following some very careful work in Edinburgh in the early 1960s. He wrote: "formal psychiatric illness occurs in probably the order of $4^{\circ}$ of students."

It seems, therefore, that many of us over the past 20 years have agreed about the size of the problem, and indeed commonly choose to avoid the word "ill," except in rare instances, when speaking of student psychological difficulties, endeavouring rather to assess and describe the extent to which the sufferer is distressed and/or handicapped as a prerequisite to deciding how the student should best be helped and, not least, by whom.

\section{BRIAN DAVY}

Department of Psychiatry,

Addenbrooke's Hospital,

Cambridge

\section{Congenital malformations and} hormones in pregnancy

SIR,-Attention has been drawn yet again to the association between hormonal preparations in pregnancy and congenital malformations. The report of a case of tracheooesophageal fistula by $\mathrm{Dr}$ Olive Frost (23 October, $p$ 978) and the letter from Dr Isabe Gal on hormonal pregnancy tests $(23$ October p 1014) stress the risk of fetal damage by the combination of oestrogen and progestogen in the contraceptive pill and pregnancy diagnosis preparations respectively.

Between 1964 and 1976 in a practice population I recorded the outcome of 13 pregnancies resulting in congenital malformations associated with a variety of hormones used

in early pregnancy. Combined oestrogen progestogen preparations were related to five infants, while progestational hormones alone were related to 9 infants. In the latter group most of the mothers had had previous early abortions and were treated by progestogens in an attempt to maintain pregnancy. The details are given in the accompanying table.

Continuation of the contraceptive pill into pregnancy will satisfy the requirement that fetal damage must occur at the time of organogenesis, but in the case of pregnancy diagnosis hormones and progestogens as used above the critical period of fetal vulnerability could well be past. It might be that in the group of progestogen-treated mothers in which there was a high fetal salvage rate defective infants had survived who would otherwise have been aborted. ${ }^{1}$

Rugeley, Staffs

Stanley Dillon

Dillon, S, Practitioner, 1970, 205, 80.

SIR,-Dr Isabel Gal (23 October, p 1014) notes that Schering Chemicals Ltd have revised the data sheet relating to the use of Primodos. The indication given for Primodos Oral in the current edition of African MIMS reads, "Secondary amenorrhoea of short duration," contrasting with the entry in the current British MIMS, which is "secondary amenorrhoea of short duration . . contraindication: pregnancy must be excluded." The package insert available in Tanzania also does not mention the potential risk of using the drug in pregnancy. The two injectable preparations of Primodos marketed in East Africa, consisting of a combination of progesterone and oestradiol benzoate, are still presented in African MIMS as indicated for the diagnosis of early pregnancy. There are, incidentally, many other examples to be found of pharmaceutical companies providing information about indications and side effects which differ between the developing world and Britain or North America.

Faculty of Medicine,

JOHN S YUDKIN

Malformations in relation to hormone administration during pregnancy

\begin{tabular}{|c|c|c|c|c|c|}
\hline Malformation & \multicolumn{2}{|c|}{ Hormone preparation } & \multicolumn{2}{|c|}{ Indication } & $\begin{array}{l}\text { Weeks of } \\
\text { pregnancy }\end{array}$ \\
\hline $\begin{array}{l}\text { Atrial and ventricular } \\
\text { septal defects }\end{array}$ & \multicolumn{2}{|c|}{ Norethynodrel + mestranol } & \multicolumn{2}{|c|}{ Contraceptive } & $1 \mathrm{st}-5 \mathrm{th}$ \\
\hline $\left.\begin{array}{l}\text { *Hypospadias } \\
\text { Bilateral inguinal } \\
\text { Hernia }\end{array}\right\}$ & \multicolumn{2}{|c|}{ Norethynodrel + mestranol } & \multicolumn{2}{|c|}{ Previous abortion } & \multirow[b]{2}{*}{ 4th-16th } \\
\hline $\left.\begin{array}{l}\text { *Bilateral hydrocoele } \\
\text { Bilateral inguinal } \\
\text { Hernia }\end{array}\right\}$ & Norethynodr & & Previo & ortion & \\
\hline $\left.\begin{array}{l}\text { Spina bifida } \\
\text { Hydrocephalus }\end{array}\right\}$ & \multicolumn{2}{|c|}{ Ethinyloestradiol + norethisterone } & \multicolumn{2}{|c|}{ Pregnancy diagnosis } & 6 th \\
\hline $\begin{array}{l}\text { Transposition of great } \\
\text { vessels }\end{array}$ & \multirow{2}{*}{\multicolumn{2}{|c|}{ Hydroxyprogesterone caproate }} & \multirow{2}{*}{\multicolumn{2}{|c|}{$\begin{array}{c}", " \\
\text { Previous abortion }\end{array}$}} & 4th \\
\hline Anencephalus & & & & & 6th-28th \\
\hline $\left.\begin{array}{l}\text { Spina bifida } \\
\text { Hydrocephalus }\end{array}\right\}$ & " & " & ", & " & 8th-26th \\
\hline Fallot's tetralogy & " & " & ", & " & 6th-28th \\
\hline Common truncus & ” & " & ", & " & 8th-28th \\
\hline Cataract & ” & $"$ & " & " & 5th-24th \\
\hline Ventricular septal defect & " & " & " & " & 12th-20th \\
\hline Arthrogryposis & Dihydrogest & & ” & " & 8th-24th \\
\hline Hypospadias & Dimethisterc & & ", & ” & 5th-8th \\
\hline Hydrocephalus & Norethistero & & Polym & hoea & $1 \mathrm{st}-3 \mathrm{rd}$ \\
\hline
\end{tabular}

*Twins. 